\title{
Application of the law of diminishing returns to describing the relationship between metabolizable energy intake and growth rate in broilers
}

\author{
H. Darmani Kuhi, E. Kebreab, E. Owen and J. France
}

The University of Reading. Department of Agriculture Earley Gate, Reading RG6 6AR, UK

(Reccived 4 June 2001; accepted 6 November 2001)

\section{ABSTRACT}

A monomolecular equation was constructed and seven published data sets were used to evaluate it with regard to its ability to describe the relationship between metabolizable energy intake and growth rate in broilers. The monomolecular takes the form:

$$
G=G_{m a x}\left(1-\mathrm{e}^{-K\left(1-m^{\prime}\right)}\right)
$$

where $G$ is liveweight gain ( $\mathrm{g} / \mathrm{g}$ of $\mathrm{LW} / \mathrm{d}$ ), $I$ is metabolizable energy intake $\left(\mathrm{kJ} / \mathrm{g}\right.$ of $\mathrm{LW} / \mathrm{d}$ ), and $G_{\max }$, $K$ and $I_{m}$ are growth parameters. This equation was used with non-linear regression to estimate the parameters and combine them to determine other biological indicators. The estimates of metabolizable energy requirement for maintenance varied between $457-655(\mathrm{~kJ} / \mathrm{kg}$ of $\mathrm{LW} / \mathrm{d})$, depending on the data set. Predictions of average metabolizable energy requirement to produce $1 \mathrm{~g}$ of liveweight gain varied from 9 to $13 \mathrm{~kJ}(2.2-3.08 \mathrm{kcal})$. These results show good agreement with previous studies. The present study demonstrates that the monomolecular equation is suitable for using as a simple inputoutput device relating metabolizable energy intake to growth rate in broilers.

KEYWORDS: broilers, monomolecular equation, metabolizable energy intake, growth rate

\section{INTRODUCTION}

The monomolecular (or Mitscherlich) equation was developed by Spillman and co-workers at the USDA as a form of the law of diminishing returns to describe the liveweight (LW) of an animal as a function of its food consumption (Spillman and Lang, 1924). Similarly, Parks (1970) proposed the monomolecular to describe 
postnatal growth of animals to early adulthood as a function of cumulative food consumption, with use of the equation shown by application to growth data on the pig. Brody (1945) used the monomolecular in conjunction with the exponential to account for sigmoidal growth patterns over time. He describes growth as 'self accelerating' (exponential) before and 'self inhibiting' (monomolecular) after time $t^{*}$, the age of puberty. Thus the Brody equation describes sigmoidal behaviour but with a discontinuity at the point of inflexion $t=t^{*}$ reflecting (according to Brody, 1945) the switch from being vegetative to being procreative. Blaxter and Boyne (1978) proposed the monomolecular for describing the relationship between energy retention and feed intake, based on a detailed analysis of over 80 calorimetric experiments with sheep and cattle. This presupposes that the response of energy retention rate to increments in (the rate of) feed intake obeys the law of diminishing returns over all levels of intake. The monomolecular equation forms an integral part of the metabolizable energy (ME) system currently used in feeding growing ruminants in the United Kingdom (ARC, 1980). NRC (1994), p. 1, states that few nutritional models are available for poultry, primarily because data to support the development of these models are scarce, and advocates that additional research is necessary to determine maintenance requirements and partial efficiencies of nutrient use for growth versus egg production. NRC (1987), however, gives some equations for estimating the energy and amino acid requirements of poultry.

In this study, the monomolecular equation is evaluated with regard to its ability to describe the relationship between ME intake and growth rate in broilers. A mathematical model is constructed and applied to 7 sets of experimental data taken from the literature.

\section{MATERIAL AND METHODS}

\section{The model}

Let $G$ (g of LWG/g of LW/d) be the rate of $\mathrm{LW}$ gain (LWG) of a broiler and I $(\mathrm{kJ} / \mathrm{g}$ of $\mathrm{LW} / \mathrm{d})$ the level of ME intake. Then:

$$
\frac{\mathrm{d} G}{\mathrm{~d} l}=K\left(G_{\max }-G\right)
$$

where $G_{\max }$ (g of LWG/g of LW/d) is the maximal attainable rate of $\mathrm{LW}$ gain and $K$ $(\mathrm{kJ} / \mathrm{g} \text { of } \mathrm{LW} / \mathrm{d})^{-1}$ is a parameter linking $\mathrm{LWG}$ and the efficiency of ME utilization for growth (equation (4)). Scaling ME intake and LW gain by body size (i.e. LW) enables account to be taken of size differences between birds. Equation (1) is similar to the monomolecular growth function, where the growth rate is a function not 
of growth already made, but of growth yet to be made to reach maturity (France and Thornley, 1984, p. 79). The initial conditions on equation (1) are $I=I_{m^{\prime}} G=0$, where $I_{m}(\mathrm{~kJ} / \mathrm{g}$ of LW/d) denotes ME intake at maintenance. Equation (1) is easily integrated:

$$
\int_{0}^{G} \frac{\mathrm{d} G}{G_{\max }-G}=\mathrm{K} \int_{I_{m}}^{I} \mathrm{~d} I
$$

giving a monomolecular equation:

$$
G=G_{\max }\left(1-\mathrm{e}^{-K\left(l-I_{m}\right)}\right)
$$

Equations (1) and (3) are illustrated in Figure 1. The slope $\mathrm{d} G / \mathrm{d} I$ decreases continually and there is no point of inflexion. This can be seen from the second differential, obtained by differentiating equation (1), which is only zero for $I \rightarrow \infty$ or $G \rightarrow G_{\max }$.

Some useful biological indicators emerge from this analysis. The parameters $G_{\max }$ and $I_{m}$ give maximum growth rate and ME intake at maintenance, respectively. $k_{g}(\mathrm{~g}$ of $\mathrm{LW} / \mathrm{kJ})$, the instantaneous efficiency of ME utilization for growth, is given by:

$$
k_{g}=\frac{\mathrm{d} G}{\mathrm{~d} I}=K\left(G_{\max }-G\right)
$$

Therefore, the maximum value of $k_{g}$ is given by the product $K^{*} G_{\max }$ and occurs when $G$ equals 0 (i.e. at maintenance). The minimum value of $k_{g}$ is 0 , which occurs
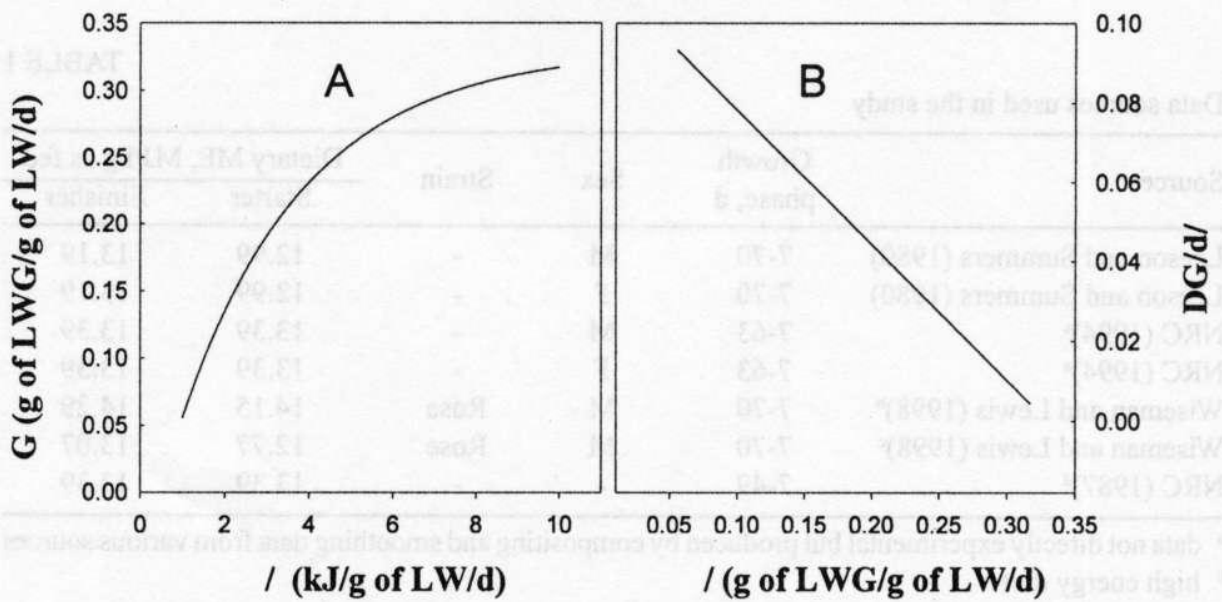

Figure 1. The monomolecular equation. The lines illustrate (A) equation (3) and (B) equation (1) expressed as a function of $I$, with $G_{\max }=0.33, K=0.34$ and $I_{m}=0.457$ 
when $G$ equals $G_{\max }$. The average efficiency of ME utilization for growth between maintenance and $\Delta$ times maintenance $(\Delta>1)$ is:

$$
\vec{k}_{g}=\frac{\int_{I_{m}}^{\Delta I_{m}} k_{g} \mathrm{~d} I}{(\Delta-1) I_{m}}=\frac{\int_{0}^{G_{\Delta m_{m}}} \mathrm{~d} G}{(\Delta-1) I_{m}}=\frac{G_{\Delta I_{m}}}{(\Delta-1) I_{m}}
$$

where $G_{\Delta l_{m}}$ is the value of $G$ when $I$ equals $\Delta I_{m}$. On using equation (3) to substitute for $G_{\Delta I_{m 1}}$, equation (5) yields:

$$
\bar{k}_{\mathrm{g}}=\frac{G_{\mathrm{max}}\left(1-\mathrm{e}^{-K(\Delta-1) l_{m}}\right)}{(\Delta-1) I_{m}}
$$

Note that $\bar{k}_{g}$ depends solely on the location of the points maintenance and $\Delta$ times maintenance, and is not affected by the curvature of the response between these two points.

\section{The experimental data}

Seven different data sets were taken from the literature and used to test the representation of the law of diminishing returns to describe the relationship between ME intake and growth rate in broilers. Details of experimental characteristics (those that were available from the literature including source, growth phases, sex, strains and dictary characteristics) are shown in Tables 1 and 2.

The monomolecular equation was fitted to these data using the software SigmaPlot (SPSS, 1998). A number of statistical criteria were used to evaluate the

TABLE 1

Data sources used in the study

\begin{tabular}{lccccc}
\hline Source & $\begin{array}{c}\text { Growth } \\
\text { phase, }\end{array}$ & Sex & Strain & & \multicolumn{2}{c}{ Dietary ME, MJ/kg as fed } \\
\cline { 5 - 6 } & $7-70$ & M & - & 12.99 & 13.19 \\
Leeson and Summers (1980) & $7-70$ & F & - & 12.99 & 13.19 \\
Leeson and Summers (1980) & $7-63$ & M & - & 13.39 & 13.39 \\
NRC (1994) & $7-63$ & F & - & 13.39 & 13.39 \\
NRC (1994) & $7-70$ & M & Rose & 14.15 & 14.29 \\
Wiseman and Lewis $(1998)^{b}$ & $7-70$ & M & Rose & 12.77 & 13.07 \\
Wiseman and Lewis $(1998)^{c}$ & $7-49$ & - & - & 13.39 & 13.39 \\
NRC (1987) & & &
\end{tabular}

a data not directly experimental but produced by compositing and smoothing data from various sources

b high energy dict

c commercial diet

¿ based on an equation by Hurwitz et al.(1978), namely:

$\mathrm{ME}(\mathrm{kcal} / \mathrm{d})=1.91 \mathrm{BW} \mathrm{W}^{0.66}+2.05 \Delta W$, where BW is body weight $(\mathrm{g})$ and $\Delta W$ is gain $(\mathrm{g} / \mathrm{d})$ 
TABLE 2

The experimental data sets.

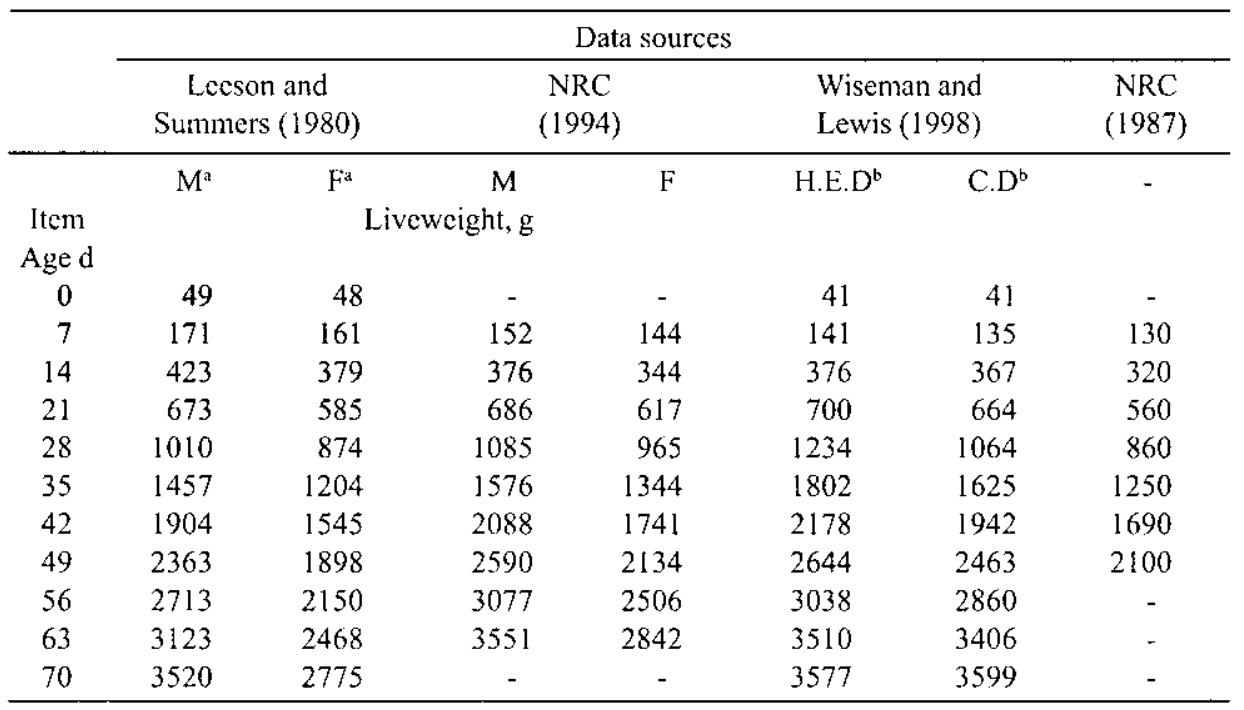

$\mathrm{M}=$ male and $\mathrm{F}=$ female

${ }^{b}$ H.E.D $=$ high energy diet and C.D = commercial diet

general goodness-of-fit of the model, including the adjusted values of proportion of variation accounted for $\left(r^{2}\right)$, standard error (SE) and Durbin-Watson (DW) statistic. The $\ddot{r}^{2}$ was calculated as, $1-\frac{S S E /(n-p)}{S_{\mathrm{y}}^{2}(n-1)}$, where $S S E$ (the residual sums of squares) is a measure of the variability in liveweight remaining after the age variable (the regressor variable) has been considered, $n$ is number of data points, $p$ is number of parameters included in the model and $S_{y}^{2}$ (the total variation of the $y$-variable) is a measure of the variability in liveweight without considering the effect of the age variable.

\section{RESULTS}

The results show that the monomolecular equation constructed can be fitted without difficulty to the different data sets using non-linear regression (Figure 2).

Table 3 shows the regression of weekly ME intake $(\mathrm{kJ} / \mathrm{g}$ of $\mathrm{LW} / \mathrm{d})$ versus body weight gain ( $\mathrm{g}$ of $\mathrm{LWG} / \mathrm{g}$ of $\mathrm{LW} / \mathrm{d}$ ) for the individual and pooled data sets. The values of $r^{-2}, \mathrm{SE}$ and the DW statistic are shown in Table 3, along with the values of the growth parameters. These criteria show that the fit of the model constructed 


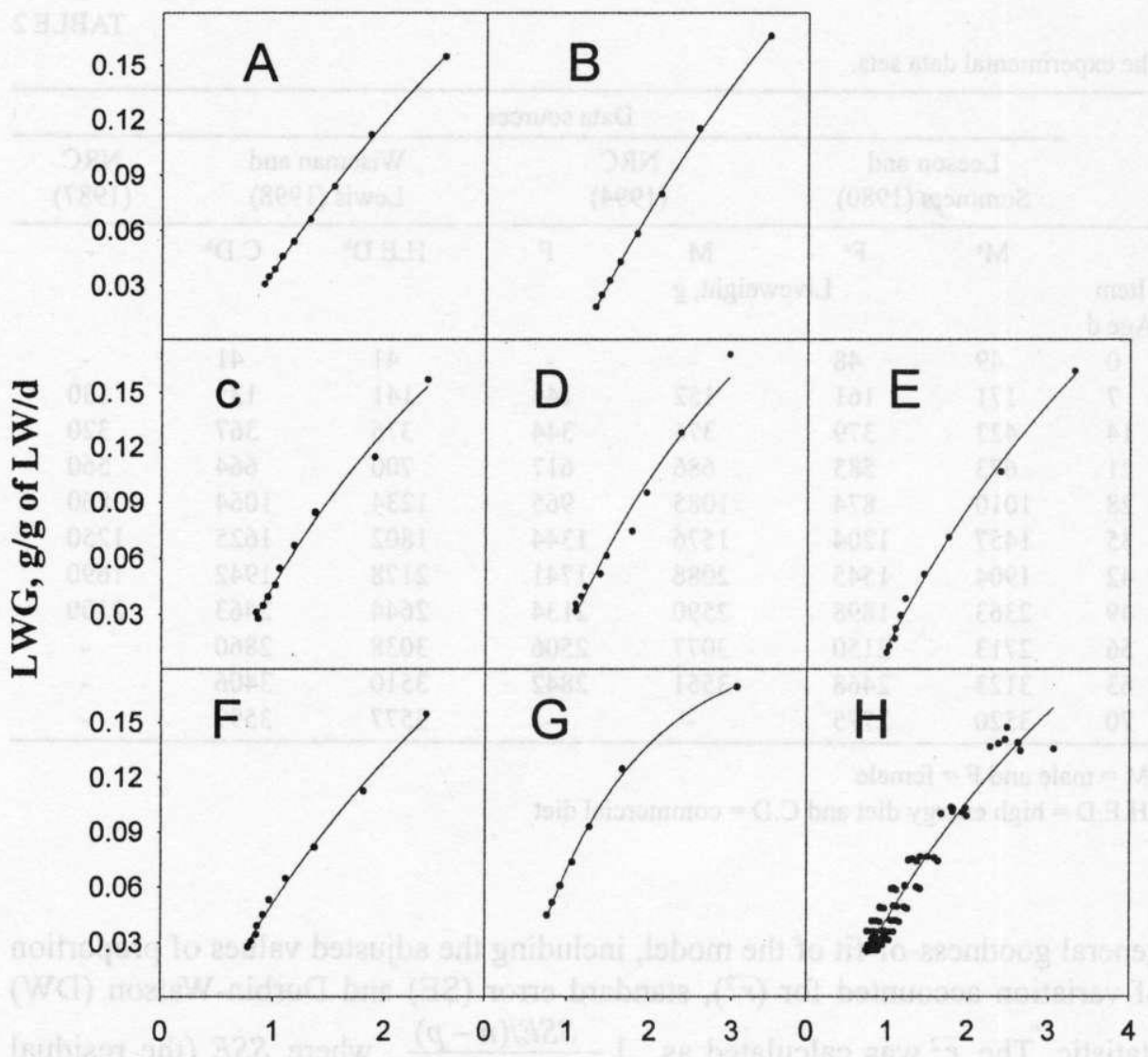

ME intake, $\mathrm{kJ} / \mathrm{g}$ of $\mathrm{LW} / \mathrm{d}$

Figure 2. Plot of different data sets showing the monomolecular model fitted. Key: (A) NRC (1994), male; (B) NRC (1994), female; (C) Wiseman and Lewis (1998), commercial; (D) Wiseman and Lewis (1998), high energy; (E) Leeson and Summer (1980), male; (F) Leeson and Summer (1980), female; (G) NRC (1987); and (H) pooled data

is acceptable for all the data sets with the exception of the commercial diet, though the monomolecular equation provided a fit to this data set and gave a maximum liveweight gain of $G_{\max }=0.26$. The $\bar{r}^{2}$, for the different data sets show that most of the variation in $G$ is accounted for by the regression. If the commercial diet is ignored, Table 3 shows data sets from the same source yield quite similar growth parameter estimates regardless of sex. Extrapolation of the curves shown in Figure 2 gives the point at which $G$ becomes zero, i.e. there is no gain in weight. Therefore, 
TABLE 3

Growth parameters ( $\pm \mathrm{SE}$ ) estimated for the different data sets using the monomolecular function, together with goodness of fit

\begin{tabular}{lccccc}
\hline Data source & $K(\mathrm{~kJ} / \mathrm{g} \mathrm{LW} / \mathrm{d})^{-1}$ & $G_{\text {max }}(\mathrm{g} / \mathrm{g} \mathrm{LW} / \mathrm{d})$ & $I_{m}(\mathrm{~kJ} / \mathrm{g} \mathrm{LW} / \mathrm{d})$ & $r^{2}$ & $\mathrm{DW}$ \\
\hline NRC (1994) (Male) & $0.240 \pm 0.037$ & $0.407 \pm 0.046$ & $0.618 \pm 0.016$ & 99.9 & 2.31 \\
NRC (1994) (Female) & $0.244 \pm 0.041$ & $0.390 \pm 0.049$ & $0.655 \pm 0.019$ & 99.9 & 2.46 \\
High encrgy dict (Malc) & $0.293 \pm 0.088$ & $0.399 \pm 0.058$ & $0.612 \pm 0.054$ & 98.9 & 2.60 \\
Commercial diet (Male) & $0.480 \pm 0.295$ & $0.260 \pm 0.110$ & $0.622 \pm 0.070$ & 97.1 & 1.06 \\
Leeson and Summers (1980) (M) & $0.340 \pm 0.120$ & $0.327 \pm 0.081$ & $0.457 \pm 0.043$ & 99.3 & 1.30 \\
Leeson and Summers (1980) (F) & $0.337 \pm 0.132$ & $0.326 \pm 0.091$ & $0.494 \pm 0.043$ & 99.3 & 1.09 \\
NRC (1987) & $0.809 \pm 0.069$ & $0.173 \pm 0.005$ & $0.453 \pm 0.027$ & 99.7 & 1.90 \\
Pooled data & $0.280 \pm 0.116$ & $0.343 \pm 0.104$ & $0.478 \pm 0.054$ & 93.7 & 1.57 \\
\hline
\end{tabular}

the intersection of the curves with $x$-axis represents the maintenance level of dietary ME intake, $I_{m}$. The estimated values of $I_{m}$ were different, depending on the data source used. The range was from $457 \mathrm{~kJ} / \mathrm{kg}$ of LW/d for the male data set of Leeson and Summer (1980) to $655 \mathrm{~kJ} / \mathrm{kg}$ of LW/d for the female data set of NRC (1994).

The indicators calculated from these parameter estimates are shown in Table 4. The maximum value of $k_{\mathrm{g}}$, the efficiency of utilization of ME for growth, is given by the product $K^{*} G_{\max }$ and there appears to be no strong evidence that $K^{*} G_{m a x}$, with an average of $0.113 \mathrm{~g}$ of LWG/kJ and a standard deviation of 0.015 , is not constant over the different data sets. The results for average $M E$ requirement to produce $1 \mathrm{~g}$ of LWG over the whole period of growth (the $1 / k_{g}$ column in Table 4) show that it varied from $9-13 \mathrm{~kJ}$ depending on the data set. From the values of $k_{g}$ for the

TABLE 4

Growth indicators calculated for the different data sets

\begin{tabular}{lcccccc}
\hline Data source & $\begin{array}{r}K^{*} G_{\max } \\
(\mathrm{g} \mathrm{LWGJ})\end{array}$ & $1 / k_{g}(\mathrm{~kJ})$ & $k_{s}{ }^{\mathrm{a}}$ & $k_{g}(1-2)^{\mathrm{b}}$ & $k_{s}(2-3)^{\mathrm{b}}$ & $\bar{k}_{g}(2-4)^{\mathrm{h}}$ \\
\hline NRC (1994) (Male) & 0.098 & 12.33 & 0.081 & 0.091 & 0.078 & 0.073 \\
NRC (1994) (Female) & 0.095 & 12.90 & 0.076 & 0.088 & 0.075 & 0.070 \\
Higl cnergy dict (Male) & 0.117 & 10.00 & 0.090 & 0.083 & 0.100 & 0.107 \\
Commercial dict (Male) & 0.081 & 9.00 & 0.125 & 0.072 & 0.111 & 0.109 \\
Lceson and Summers (1980) (M) & 0.111 & 11.27 & 0.082 & 0.088 & 0.089 & 0.103 \\
Leeson and Summers (1980) (F) & 0.086 & 11.34 & 0.110 & 0.080 & 0.088 & 0.102 \\
NRC (1987) & 0.140 & 13.00 & 0.077 & 0.097 & 0.082 & 0.072 \\
Pooled data & 0.096 & 13.00 & 0.077 & 0.084 & 0.078 & 0.074 \\
\hline
\end{tabular}

" average efficiency of ME utilization for growth ( $\mathrm{g}$ of $\mathrm{LWG} / \mathrm{kJ}$ ) over the whole growth phase

"average efficiency of ME utilization for growth ( $\mathrm{g}$ of $\mathrm{LWG} / \mathrm{kJ}$ ) between 1-2, 2-3 and 2-4 times maintenance 
different levels of feeding, it can be seen that the efficiency of utilization of ME for growth is greatest at low intake levels (when the birds are young), and decreases as intakes increase (as the birds age). The valuc of $k_{g}$ will approach 0 when the birds reach maturity. Also, the value of $k_{g}$ for the male broilers is greater than for the female broilers for the same data source.

\section{DISCUSSION}

NRC (1994) states that few nutritional models are available for poultry and suggests that additional research is necessary to determine maintenance requirements and partial efficiencies of nutrient utilization for the different production purposes. Therefore, the main aim of this study was to evaluate the monomolecular equation with regard to its ability to describe the relationship between $\mathrm{ME}$ intake and LWG. The results of fitting the monomolecular to data show that it is capable of describing this relationship with a high degree of accuracy $\left(r^{2}=0.93\right)$. The low values obtained for the standard errors of the growth parameters (and therefore cstimated small confidence interval, which measures the overall quality of the regression line), are further evidence of the close agreement that can be obtained between observed and predicted LWG in response to ME intake using this equation. Titus et al. (1934) observed that when chickens are fed at different levels of intake, varying from $40-100 \%$ ad libitum feed consumption, liveweights of less than approximately $500 \mathrm{~g}$ could be described by a single equation relating liveweight to cumulative feed consumption, regardless of the level of intake. The results of this study also show that the pooled data set can be described by a single equation with a high degree of accuracy $\left(\bar{r}^{2}=0.95\right)$, in spite of differences that exist between the individual sets (such as dietary energy and protein, sex and management).

The results obtained for $I_{m}$, the ME intake at maintenance, for the different data sets are difficult to compare as the experimental conditions were different in some respect (e.g. management and nutrition), and may be subject to environmental differences. However, the estimated values of $I_{m}$ obtained by fitting the monomolecular to the different data sets lie in the range $450-800 \mathrm{~kJ} / \mathrm{kg}$ of LW/d previously reported by different researchers (Farrell and Siregar, 1980; Pym et al., 1984; Kirchgessner et al., 1989). Wiseman (1994) states that, depending upon the author, the cost of $1 \mathrm{~g}$ of LWG, i.e. $1 / k_{g}$, is between $8.8-13.0 \mathrm{~kJ}(2.1-3.1 \mathrm{kcal})$. In this study, $1 / \bar{k}_{g}$ varied from $9.0-13 \mathrm{~kJ}(2.2-3.08 \mathrm{kcal})$ depending upon the data source, which is in good agreement with the range reported by Wiseman (1994). The results of this study for $\bar{k}_{g}$ are supported by conventional wisdom, namely that a gradual decrease in utilization of ME for producing gain occurs as birds age and that male broilers are superior to females in using ME for gain. 
Hurwitz et al. (1978) give higher estimates of $I_{m}$ (763 vs $453 \mathrm{~kJ} / \mathrm{kg}$ of $\mathrm{LW} / \mathrm{d}$ ) at a cost of an underestimation of $1 / \bar{k}_{g}$ (a fixed value of $8.6 \mathrm{~kJ} / \mathrm{g}$ of LWG vs an average value of $13 \mathrm{~kJ} / \mathrm{g}$ of LWG ), compared to those obtained when the monomolecular was fitted to the NRC (1987) data set, generated from an equation reported by the same authors. These discrepancies are a consequence of assumptions made by Hurwitz et al. (1978) in constructing their growth model, namely the ME requirements for maintenance and for growth have to be independent constants. The latter assumption must be an oversimplification. As the bird grows, the composition of gain changes from predominantly protein in the early stages to a greater proportion of adipose tissue as the bird approaches maturity. Each successive increment of weight gain will therefore require a greater input of energy, in view of the greater energy content and lower water content of adipose tissue compared to non-fat tissue.

In conclusion, this study demonstrates that the monomolecular equation which can estimate the different growth parameters without having any initial assumptions (constraints) and allows the efficiency of ME utilization for growth to change, as expected as birds aged, is suitable for using as a simple input-output device relating $\mathrm{ME}$ intake to growth rate in broiler chicks.

\section{REFERENCES}

ARC, 1980. The Nutrient Requirements of Ruminant Livestock. Commonwealth Agricultural Bureaux, Slough (UK)

Blaxter K.L., Boyne A.W., 1978. The estimation of the nutritive value of feeds as energy sources for ruminants and the derivation of feeding systems. J. Agr. Sci. 90, 47-68

Brody S., 1945. Bioenergetics and Growth. Rheinhold Publishing, New York, NY

Farrell D.J., Siregar A.P., 1980. Comparison of the energy exchanges of ducklings and chickens. In: L.E. Mount (Editor). Energy Metabolism of Farm Animals. Butterworth, London (UK), pp. $119-123$

France J., Thornley J.H.M., 1984. Mathematical Models in Agriculture. Butterworths, London (UK)

Hurwitz S.D., Sklan D., Bartov I., 1978. New formal approaches to the determination of energy and amino acid requirements of chicks. Poultry Sci. 57, 197-205

Kirchgessner M., Maurus-Krukal E.M., Roth F.X., 1989. Energy utilization of broilers between 1500 and $3000 \mathrm{~g}$ liveweight. In: Y. van der Honing, W.H. Close (Editors). Energy Metabolism of Farm Animals. Pudoc, Wageningen (The Netherlands), pp. 5-8

Leeson, S., Summers J. D., 1980. Production and carcass characteristics of the broiler chicken. Poultry Sci. 59, 786-798

NRC, 1987. Predicting Feed Intake of Food-Producing Animals. National Academy Press, Washington, DC

NRC, 1994. Nutrient Requirements of Poultry. $9^{\text {th }}$ revised Edition. National Academy Press, Washington, DC

Parks J.R., 1970. Growth curves and the physiology of growth. I. Animals. Amer. J. Physiol. 219, 833-836 
Pym R.A.E., Nicholls P.J., Thomson E., Choice A., Farrell D.J., 1984. Energy and nitrogen metabolism of broilers selected over ten generations for increased growth rate, food consumption and conversion of food to gain. Brit. Poultry Sci. 25, 529-539

Spillman W.J., Lang E., 1924. The Law of Diminishing Incement. World Book Co., Chicago, IL Titus H.W., Moran A.J., Hendricks A., 1934. Growth of chicks as a function of feed consumption. J. Agr. Res. $48,817-835$

SPSS, 1998. SigmaPlot 5.0 User's Guide. SPSS Inc. Chicago, IL

Wiseman, J., 1994. Nutrition and Feeding of Poultry. Nottingham University Press, Loughborough (UK)

Wiseman, J., Lewis C.E., 1998. Influence of dietary encrgy and nutrient concentration on the growth of body weight and of carcass components of broiler chickens. J. Agr. Sci. 131, 361-371

\section{STRESZCZENIE}

Zastosowanie reguly malejącej efektywności do opisu zależności między zużyciem energii metabolicznej i tempem wzrostu brojlerów

W pracy przedstawiono metodę do opisu zależności między zużyciem energii metabolicznej i tempem wzrostu brojlerów. Zależność ta wyraża się następującym równaniem:

$$
G=G_{m m x x}\left(1-e^{-K\left(1-t_{n}\right)}\right)
$$

gdzie: G - przyrost masy ciała (g/g masy ciała/dzicń), $I$ - ilość pobranej energii metabolicznej (kJ/g masy ciała/dzień), $G_{\max }, K \mathrm{i} I_{\mathrm{m}}$ - parametry wzrostu.

Weryfikację przydatności zaproponowanej metody przeprowadzono wykorzystując siedem zestawów danych pochodzących z literatury. Do estymacji parametrów równania i innych biologicznych wskaźników (jako funkcji parametrów) wykorzystano metodę regresji krzywoliniowej. Oszacowane zapotrzebowanie energii metabolicznej na potrzeby bytowe wahało się od $457 \mathrm{do} 655(\mathrm{~kJ} / \mathrm{kg}$ masy ciała/dzień) w zalcżności od zestawu danych. Oszacowanie przeciętnego zapotrzebowania na cnergiç metaboliczną na $1 \mathrm{~g}$ przyrostu masy ciała wynosilo od 9 do $13 \mathrm{~kJ}(2.2$ do $3,08 \mathrm{kcal})$. Wyniki te zgodne są z otrzymanymi wcześniej, i wskazują na przydatność zaprezentowanego równania do określania zależności między pobraniem energii metabolicznej a tempem wzrostu brojlerów. 